\title{
Resting Metabolism in Hypoxia-acclimated Rats during Acute Hypoxic Exposure
}

\author{
Masao Hayashi and Tetsuo Nagasaka \\ Department of Physiology, School of Medicine, Kanazawa University, \\ Kanazawa, Ishikawa, 920 Japan
}

\begin{abstract}
Summary In contrast to the decreased metabolism in non-hypoxiaacclimated (CT) rats, acute hypoxia $\left(9.5 \% \mathrm{O}_{2}\right)$ did not change the resting metabolism in hypoxia-acclimated ( $\mathrm{HX}: 12 \% \mathrm{O}_{2}$ for 2 months) rats at $25^{\circ} \mathrm{C}$. After $\beta$-adrenergic blockade, acute hypoxia greatly reduced the resting metabolism in $\mathrm{HX}$ rats. The calorigenic response to norepinephrine $\left(0.4 \mathrm{mg} \cdot \mathrm{kg}^{-1}\right)$ during acute hypoxia was, however, identical with that observed in CT rats. These results suggest an enhanced $\beta$ adrenergic stimulation in $\mathrm{HX}$ rats during acute exposure to hypoxia.

Key Words: hypoxia-acclimation, resting metabolism, $\beta$-adrenergic stimulation.
\end{abstract}

Acute hypoxia $\left(9.5 \% \mathrm{O}_{2}\right)$ suppressed resting metabolism in non-hypoxiaacclimated freely moving rats at an ambient temperature of $25^{\circ} \mathrm{C}$ (HAYASHI and NAGASAKA, 1981). After acclimation to hypoxia $\left(12 \% \mathrm{O}_{2}\right)$, however, the same rats maintained a relatively higher metabolism in acute hypoxia. This was accompanied by a marked tachycardia, which was suggested to be due to an enhanced sympatho-adrenal activity (HAYASHI and NAGASAKA, 1982). When the non-hypoxia-acclimated rats were lightly restrained, they responded to acute hypoxia with increased metabolism, which was completely abolished after sympathetic blockade (HAYASHI and NAGASAKA, 1981). All these data indicate the importance of sympatho-adrenal activity in maintaining a higher-than-normal metabolic rate in hypoxic environments. The aim of this study is to ascertain the extent of the contribution of the sympatho-adrenal system to the maintenance of higher metabolism during acute hypoxia in hypoxia-acclimated rats.

Forty-eight male Wistar rats were used in this experiment. Twenty-four rats were kept in a normoxic environment at $24 \pm 1^{\circ} \mathrm{C}$ for at least 2 weeks (nonhypoxia-acclimated: CT). The other 24 rats were housed, 6 rats together, in a metal box $(40 \times 36 \times 26 \mathrm{~cm})$ to which premixed hypoxic gas $\left(12 \% \mathrm{O}_{2}\right.$ in $\left.\mathrm{N}_{2}\right)$ was continuously fed $\left(3.7\right.$ liters $\left.\cdot \mathrm{min}^{-1}\right)$ for 2 months (hypoxia-acclimated: HX). The

Received for publication November 27, 1981

林 正男, 永坂鉄夫 
temperature inside the box was kept at $24 \pm 1^{\circ} \mathrm{C}$. The lid of the box was opened once every day (within $20 \mathrm{~min}$ ) to dispose of the waste and to replenish with food and water. All rats were fed a commercial rat chow (Oriental MF, Oriental Yeast Co., Tokyo) and water ad libitum. Before testing, body weights of CT and $\mathrm{HX}$ rats were $352 \pm 4$ and $347 \pm 5 \mathrm{~g}$, respectively. Both CT and HX rats were divided into two groups; one was treated with $\beta$-adrenergic blocker ( $d l$-propranolol) and the other injected with $l$-norepinephrine bitartrate (NE). On the test day, one rat from each group was transferred to the laboratory at 8:30 a.m., and a thermistor probe was irserted $7 \mathrm{~cm}$ into the colon for temperature measurement (Tcol). A polyethylene tube $(0.6 \mathrm{~mm}$ o.d.) was inserted into the intraperitoneal cavity through the overlying skin for injection of propranolol or NE. At 9: 00 a.m., the rat was placed in a wire mesh cage $(8 \times 8 \times 18 \mathrm{~cm})$, and was transferred into a metabolic chamber whose wall temperature was kept at $25.0 \pm$ $0.1^{\circ} \mathrm{C}$. Oxygen consumption $\left(\dot{V}_{\mathrm{O}_{2}}\right)$ was measured by a closed circuit system essentially the same as reported by HeUSNER et al. (1971) except that the air inside was circulated by a pump in the system. The surface area (SA in $\mathrm{m}^{2}$ ) of the rat was estimated from the body weight (Wt in $\mathrm{kg}$ ) using the following equation: $\mathrm{SA}=0.091 \mathrm{Wt}^{2 / 3}$ (DAwson et al., 1970). After a steady state had been reached, the air inside the system was replaced with $9.5 \% \mathrm{O}_{2}$ in $\mathrm{N}_{2}$ gas for $20 \mathrm{~min}$ at about 12: 00 a.m.

Propranolol $\left(4.0 \mathrm{mg} \cdot \mathrm{kg}^{-1}\right)$ was injected $20 \mathrm{~min}$ before exposure to hypoxia. To keep an adequate blockade throughout the experiment, an additional dose of $2.0 \mathrm{mg} \cdot \mathrm{kg}^{-1}$ was given every $15 \mathrm{~min}$ thereafter. Difficulty of breathing in rats following propranolol injection was not noticed in this experiment. Calorigenic responses to $\mathrm{NE}\left(0.4 \mathrm{mg} \cdot \mathrm{kg}^{-1}\right)$ were observed under normoxia, at 80 or $160 \mathrm{~min}$ in hypoxia.

Results were expressed as means \pm S.E. The Student $t$-test was applied to determine statistically significant differences. Significance levels of $p<0.05$ were chosen.

Figure 1 shows changes in $\dot{V}_{\mathrm{O}_{2}}$ and Tcol following hypoxic exposure in the non-propranolol-treated (intact) (A) and in the propranolol-treated rats (B). $\dot{V}_{\mathrm{O}_{2}}$ and $T$ col decreased significantly in the intact CT rats during hypoxia. $\dot{V}_{\mathrm{O}_{2}}$ were $2.31 \pm 0.04 \mathrm{ml} \cdot \mathrm{sec}^{-1} \cdot \mathrm{m}^{-2}$ in normoxia and $1.94 \pm 0.06 \mathrm{ml} \cdot \mathrm{sec}^{-1} \cdot \mathrm{m}^{-2}$ at $40 \mathrm{~min}$ in hypoxia in CT rats. Tcol, which was $37.0 \pm 0.12^{\circ} \mathrm{C}$ in normoxia, continuously decreased during hypoxia in CT rats. Tcol reached $35.9 \pm 0.20^{\circ} \mathrm{C}$ at $160 \mathrm{~min}$ in hypoxia. The intact $\mathrm{HX}$ rats exhibited no significant change in $\dot{V}_{\mathrm{O}_{2}}$ or $T \mathrm{col}$ on acute hypoxic exposure. In the propranolol-treated rats, acute hypoxia significantly reduced $\dot{V}_{\mathrm{O}_{2}}$ and $T \mathrm{col}$ in both CT and $\mathrm{HX}$ rats. The average $\dot{V}_{\mathrm{O}_{2}}$ for 20-60 $\mathrm{min}$ after the onset of hypoxic exposure was $1.96 \pm 0.03 \mathrm{ml} \cdot \mathrm{sec}^{-1} \cdot \mathrm{m}^{-2}$ in $\mathrm{HX}$ rats, while in CT rats the average $\dot{V}_{\mathrm{O}_{2}}$ was $1.84 \pm 0.04 \mathrm{ml} \cdot \mathrm{sec}^{-1} \cdot \mathrm{m}^{-2}$. The $T \mathrm{col}$ at $60 \mathrm{~min}$ after the onset of hypoxia was $36.6 \pm 0.14^{\circ} \mathrm{C}$ in $\mathrm{HX}$ rats, whereas in CT rats the $T$ col was $36.2 \pm 0.16^{\circ} \mathrm{C}$. There were statistically significant dif- 

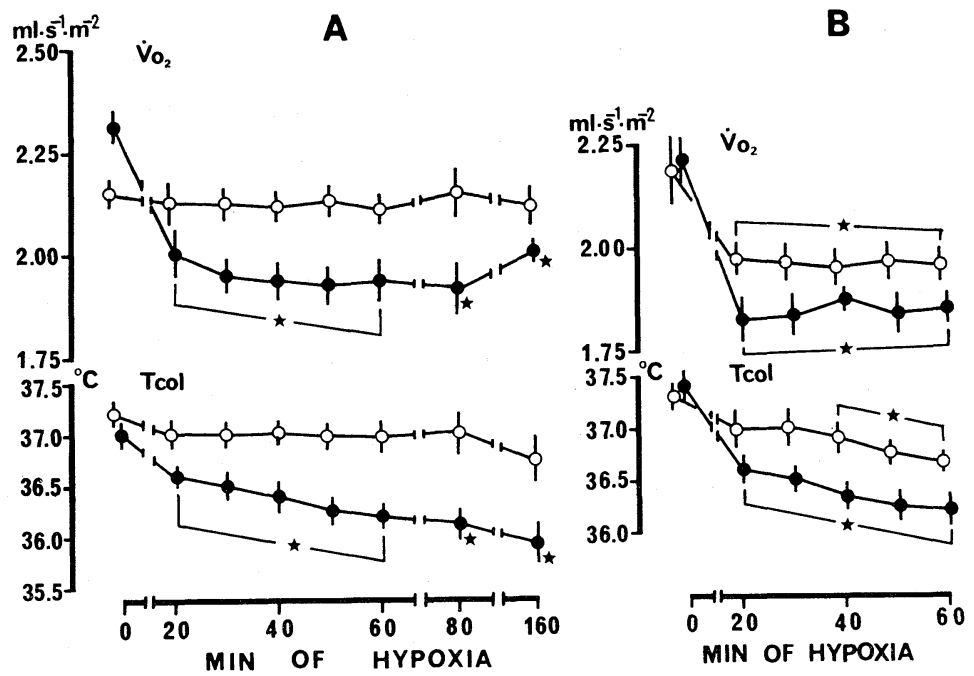

Fig. 1. Changes in oxygen consumption $\left(\dot{V}_{\mathrm{O}_{2}}\right)$ and colonic temperature $(T \mathrm{col})$ during acute hypoxia $\left(9.5 \% \mathrm{O}_{2}\right)$ in the intact $(\mathrm{A})$ and the propranolol-treated (B) rats at an ambient temperature of $25^{\circ} \mathrm{C}$. Values are means \pm S.E. of 6 rats. Open circles, hypoxiaacclimated; closed circles, non-hypoxia-acclimated control rats.
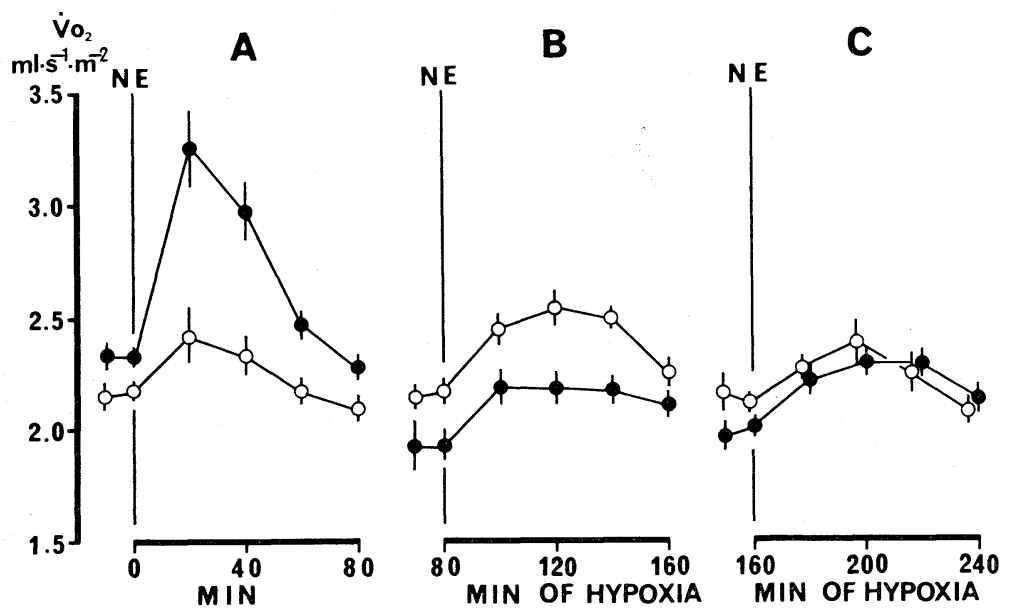

Fig. 2. Changes in $\dot{V}_{\mathrm{O}_{2}}$ of hypoxia-acclimated (O) and non-hypoxia-acclimated control (•) rats caused by $\mathrm{NE}\left(0.4 \mathrm{mg} \cdot \mathrm{kg}^{-1}\right)$ injection in normoxia (A), at $80 \mathrm{~min}$ (B) and at $160 \mathrm{~min}$ (C) after the onset of acute hypoxic exposure $\left(9.5 \% \mathrm{O}_{2}\right)$ at an ambient temperature of $25^{\circ} \mathrm{C}$. Values are means \pm S.E. of 6 rats.

ferences in $\dot{V}_{\mathrm{O}_{2}}$ and in $T$ col between $\mathrm{CT}$ and $\mathrm{HX}$ rats during hypoxic exposure.

An injection of NE $\left(0.4 \mathrm{mg} \cdot \mathrm{kg}^{-1}\right)$ increased $\dot{V}_{\mathrm{O}_{2}}$ in both intact CT and HX rats (Fig. 2). In normoxia, the amount of increase in $\dot{V}_{\mathrm{O}_{2}}$ was significantly greater 
in CT rats than $\mathrm{HX}$ rats. The maximal increase in $\dot{V}_{\mathrm{O}_{2}}$ was $0.93 \pm 0.14 \mathrm{ml} \cdot \mathrm{sec}^{-1}$. $\mathrm{m}^{-2}$ in CT rats, whereas the increase was $0.24 \pm 0.09 \mathrm{ml} \cdot \mathrm{sec}^{-1} \cdot \mathrm{m}^{-2}$ in $\mathrm{HX}$ rats. In hypoxia, the calorigenic response to NE was greatly suppressed in CT rats, while in HX rats the response was nearly the same as that observed in normoxia. At $80 \mathrm{~min}$ and at $160 \mathrm{~min}$ after the onset of hypoxic exposure, maximal increases in $\dot{V}_{\mathrm{O}_{2}}$ after NE injection were $0.27 \pm 0.06$ and $0.28 \pm 0.07 \mathrm{ml} \cdot \mathrm{sec}^{-1} \cdot \mathrm{m}^{-2}$ in CT rats and $0.37 \pm 0.10$ and $0.26 \pm 0.05 \mathrm{ml} \cdot \mathrm{sec}^{-1} \cdot \mathrm{m}^{-2}$ in $\mathrm{HX}$ rats, respectively.

Our data clearly show that at an ambient temperature of $25^{\circ} \mathrm{C}$ acute hypoxia $\left(9.5 \% \mathrm{O}_{2}\right)$ suppressed the metabolism in the intact $\mathrm{CT}$ rats, but did not change the resting metabolism in the intact $\mathrm{HX}$ rats. After $\beta$-adrenergic blockade with propranolol, however, acute hypoxia suppressed resting metabolism in HX rats. The relatively higher metabolism during hypoxia in the intact $\mathrm{HX}$ rats was, therefore, shown to be mainly due to an enhanced sympatho-adrenal activity. A single injection of $\mathrm{NE}$ at a dose sufficient to achieve a maximal calorigenic response in normoxic environment (J ANSKÝ $_{\mathrm{L}}$ et al., 1969) increased $\dot{V}_{\mathrm{O}_{2}}$ in both CT and HX rats to the same extent under hypoxia. This result suggests that the sensitivities of the peripheral calorigenic tissues to NE are almost identical in these two groups of rats under hypoxia. Greatly increased stimulation of $\beta$-adrenergic receptors might be produced in HX rats during acute hypoxic exposure. The question whether the endogenous catecholamine concentration was greatly increased by acute exposure to hypoxia needs further study. In our previous work (HAYASHI and NAGASAKA, 1982), we observed that acute hypoxia produced a tachycardia in hypoxia-acclimated rats. This hypoxia-induced tachycardia was not observed in non-hypoxia-acclimated rats, and was abolished by $\beta$-adrenergic blockade. This information together with the present results suggest that the enhanced sympatho-adrenal activity cluring acute hypoxic exposure is the characteristic property of hypoxia-acclimated rats. After $\beta$-adrenergic blockade, hypoxiaacclimated rats exhibited higher $\dot{V}_{\mathrm{O}_{2}}$ than non-hypoxia-acclimated rats during acute hypoxic exposure (Fig. 1B). Certain other mechanisms such as increased blood oxygen capacity, increased muscle myoglobin (TAPPAN and REYNAFARJE, 1957), or increased pulmonary diffusion capacity for oxygen (BURRI and WEIBEL, 1971) produced by hypoxia-acclimation may be responsible for the difference.

This study was supported by the Grants-in-Aid for Scientific Research from the Ministry of Education, Science and Culture of Japan ( $\$ 00548106$ and $\$ 56870027$ ).

\section{REFERENCES}

BURRI, P. H. and WeIBEL, E. R. (1971) Morphometric evaluation of changes in lung structure due to high altitude. In: High Altitude Physiology: Cardiac and Respiratory Aspects, Churchill Livingstone, Edinturgh and London, pp. 15-30.

Dawson, C. A., Boemer, R. B., and Horvath, S. H. (1970) Body temperature and oxygen uptake in warm- and cold-adapted rats by swimming. J. Appl. Physiol., 29: 150-154.

JANSKÝ, L., BARTU゚ŇKovÁ, R., KočKovÁ, J., MEJSNAR, J., and ZEISBERGER, E. (1969) Interspecies 
differences in cold adaptation and nonshivering thermogenesis. Fed. Proc., 28: 1052-1058.

HAYASHI, M. and NAGASAKA, T. (1981) Enhanced heat production in physically restrained rats in hypoxia. J. Appl. Physiol., 51: 1601-1606.

HAYAShI, M. and NAgASAKA, T. (1982) Hypoxic tachycardia in hypoxia-acclimated rats. Jpn. J. Physiol., 32: 149-152.

Heusner, A. A., Roberts, J. C., and Smith, R. Em. (1971) Circadian patterns of oxygen consumption in peromyscus. J. Appl. Physiol., 30: 50-55.

TAPPAN, D. V. and ReYNAFARJE, B. (1957) Tissue pigment manifestations of adaptation to high altitudes. Am. J. Physiol., 190: 99-103. 